Canadian

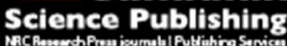

Biochemistry and Cell Biology Biochimie et biologie cellulaire

\title{
Transcript level of AKR1C3 is down-regulated in gastric cancer
}

\begin{tabular}{|c|c|}
\hline Journal: & Biochemistry and Cell Biology \\
\hline Manuscript ID & bcb-2015-0096.R1 \\
\hline Manuscript Type: & Article \\
\hline Date Submitted by the Author: & 04-Dec-2015 \\
\hline Complete List of Authors: & $\begin{array}{l}\text { Frycz, Bartosz; University of Medical Sciences, Department of Biochemistry } \\
\text { and Molecular Biology } \\
\text { Murawa, Dawid; Greater Poland Cancer Centre, ; Regional Specialist } \\
\text { Hospital , } \\
\text { Borejsza-Wysocki, Maciej; Heliodor Swiecicki Clinical Hospital at the Karol } \\
\text { Marcinkowski Medical University, } \\
\text { Wichtowski, Mateusz; Greater Poland Cancer Centre } \\
\text { Spychała, Arkadiusz; Greater Poland Cancer Centre, } \\
\text { Marciniak, Ryszard; Heliodor Swiecicki Clinical Hospital at the Karol } \\
\text { Marcinkowski Medical University, } \\
\text { Murawa, Paweł; Greater Poland Cancer Centre, } \\
\text { Drews, Michał; Heliodor Swiecicki Clinical Hospital at the Karol } \\
\text { Marcinkowski Medical University, } \\
\text { Jagodziński, Paweł; University of Medical Sciences, Department of } \\
\text { Biochemistry and Molecular Biology }\end{array}$ \\
\hline Keyword: & $\begin{array}{l}\text { gastric cancer, steroidogenesis, steroidogenic enzymes, AKR1C3, sodium } \\
\text { butyrate }\end{array}$ \\
\hline
\end{tabular}




\section{Transcript level of $A K R 1 C 3$ is down-regulated in gastric cancer}

Bartosz Adam Frycz ${ }^{1}$, Dawid Murawa ${ }^{2,3}$, Maciej Borejsza-Wysocki ${ }^{4}$, Mateusz Wichtowski ${ }^{2}$,Arkadiusz Spychała $^{2}$, Ryszard Marciniak ${ }^{4}$, Paweł Murawa ${ }^{2}$, Michał Drews ${ }^{4}$, Paweł Piotr Jagodziński ${ }^{1}$

${ }^{1}$ Department of Biochemistry and Molecular Biology, University of Medical Sciences, Poznań, Poland

${ }^{2}$ First Department of Surgical Oncology and General Surgery, Greater Poland Cancer Centre, Poznań, Poland

${ }^{3}$ Regional Specialist Hospital, Research and Development Centre, Wrocław, Poland

${ }^{4}$ Department of General, Endocrinological Surgery and Gastroenterological Oncology, University of Medical Sciences, Poznań, Poland

Postal address:

1. University of Medical Sciences, Swiecickiego 6 St., 60-781 Poznan

2. Greater Poland Cancer Centre, Garbary 15 St., 61- 866 Poznan

3. Regional Specialist Hospital in Wroclaw, Research and Development Centre,Kamienskiego 73a St., 51-124 Wroclaw

4.Heliodor Swiecicki Clinical Hospital at the Karol Marcinkowski Medical University, Przybyszewskiego 49 St., 60-355 Poznan

Corresponding author:

Bartosz Adam Frycz

e-mail:bartekfrycz@gmail.com

tel. +48 (61) 854-65-13

fax: +48 (61) 854-65-10 


\section{Abstract}

Steroid hormones are shown to play some role in gastric carcinogenesis. Large amounts of them are locally produced in peripheral tissues at both genders. Type 5 of $17 \beta$-hydroxysteroid dehydrogenase, encoded by $A K R I C 3$ gene, plays a pivotal role in both androgen and estrogen metabolism and its deregulated expression was found in different cancers. In this study we measured AKR1C3 transcript and protein levels in nontumoral and primary tumoral gastric tissues and evaluated their association with some clinicopathological features of gastric cancer (GC). We found decreased AKR1C3 transcript $(\mathrm{p}<0.0001)$ and protein $(\mathrm{p}=0.0021)$ levels in GC tissues compared to adjacent histopathologically normal appearing mucosa. Lower levels of $A K R 1 C 3$ transcript were observed in diffuse and intestinal types of GC whereas $\mathrm{AKR} 1 \mathrm{C} 3$ protein was decreased in tumors with multi site localization, in diffuse histological type, T3, T4 and G3 grades. We also determined the effect of histone deacetylases inhibitor, sodium butyrate $(\mathrm{NaBu})$, on AKR1C3 expression in EPG 85-257 and HGC-27 GC cell lines. We found that $\mathrm{NaBu}$ is able to elevate both AKR1C3 transcript and protein levels in investigated cell lines. Altogether, our results suggest that decreased expression of AKR1C3 may be involved in development of GC and can be restored by $\mathrm{NaBu}$.

Key words: gastric cancer, steroidogenesis, steroidogenic enzymes, AKR1C3, sodium butyrate 
Introduction

Despite a decreasing incidence observed during the last decades, gastric cancer (GC) remains a serious health problem in most populations (Jemal et al 2011). The risk of GC development is mainly associated with Helicobacter pylori infections, diet abundant in salty and smoked food, obesity, tobacco smoking and genetic factors (Lee and Derakhshan 2013). Moreover, epidemiological and experimental studies indicate on steroid hormones as a possible factor related to this carcinoma (Camargo et al. 2011). Estrogens seem to have a protective effect in GC etiology, according to the higher incidence of that tumor in males than females (Camargo et al. 2011). Role of androgens in GC etiology is a less elucidated and only a few studies concern that issue (Nakamura et al. 2006; Polimeno et al. 1994). Important findings in the sex steroid biology is the ability of some peripheral tissues to conversion of adrenal derived dehydroepiandrosterone, its sulfate and androstenedione (a-dione) into an active estrogens and androgens (Sasano et al. 1998; Labrie and Labrie 2013). These hormones exert their action on the same cells where its synthesis took place, without a release to the general circulation. The peripheral synthesis rate of steroid hormones is controlled by the local expression of enzymes which synthesize the estrogens and androgens from adrenal derived precursors (Labrie et al. 2000). Aberrant expression of enzymes involved in local steroidogenic pathway may lead to the formation of an abnormal intracellular steroids level and to uncontrolled cells proliferation (Brodie et al. 2009). Some evidence suggest, that changes in the expression of genes encoding steroidogenic enzymes could have a significant meaning in the etiology of hormone dependent tumors, including breast (Sasano et al. 2006), endometrial (Sasano et al. 2000), ovarian (Mungenast and Thalhammerand 2014), prostate (Gianfrilli et al. 2014) as well as in the other tumors not directly related with reproductive features like lung (Drzewiecka et al. 2015), thyroid (Rahbari et al. 2010), colon (Lin and Giovannucci 2010), central nervous system ( Park et al. 2010), or gastric (Nakamura et al. 2006; Frycz et al. 2015). One of the most important enzymes family, responsible for the interconversion between the biologically active and inactive forms of estrogens and androgens on the last steps of their biosynthesis, are 17B-hydroxysteroid dehydrogenases (HSD17Bs). There are 14 type of HSD17Bs reported of which 12 have been found in humans. HSD17Bs isoenzyme differ with the substrate specificity and tissue pattern expression (Moeller and Adamski 
2009). Additionally, it was shown that the expression of $A K R 1 C 3$ gene encoding type 5 of HSD17B, responsible for the conversion of both, a-dione to testosterone (T) and estrone (E1) to 17ß-estradiol (E2), is deregulated in multiple human cancers (Dozmorov et al. 2010; Lewis et al. 2004; Zakharov et al. 2010; Martinez et al. 2007). Therefore, according to the emerging role of steroid hormones in GC development, we measured transcript and protein levels of AKR1C3 in nontumoral and in primary tumoral gastric tissues. We also assessed the effect of histone deacetylases inhibitor, sodium butyrate $(\mathrm{NaBu})$, on the AKR1C3 transcript and protein levels in EPG 85-257 and HGC-27 GC cell lines. Additionally, we evaluated the association of AKR1C3 expression with some clinicopathological features of GC. 
Materials and methods

\section{Tissue specimens}

Primary tumoral gastric tissues and adjacent histopathologically normal appearing mucosa were collected between December 2012 and March 2015 from fifty five patients who underwent total gastrectomy at First Department of Surgical Oncology and General Surgery, Greater Poland Cancer Centre, Poznań, Poland or Department of General, Endocrinological Surgery and Gastroenterological Oncology, University of Medical Sciences, Poznań, Poland (Tab. 1). The procedures of the study were approved by the Local Ethical Committee of Poznań University of Medical Sciences. Written informed consent was obtained from all participating individuals. Histopathologically unchanged gastric mucosa situated at least $10-20 \mathrm{~cm}$ away from the tumoral lesions was obtained from the same patients. A part of the samples was immediately snap-frozen in liquid nitrogen and stored at $-80^{\circ} \mathrm{C}$ until RNA/protein isolation. Histopathological assessment was performed by an experienced pathologist.

\section{Antibodies and Reagents}

Goat polyclonal anti-AKR1C3 antibody (Ab) (ab27491) was purchased from Abcam, (Cambridge, UK). Rabbit polyclonal anti-glyceraldehyde-3-phosphate (GAPDH) Ab (SC-25778), goat anti-rabbit horseradish peroxidase (HRP)-conjugated $\mathrm{Ab}$ (SC-2004) and rabbit anti-goat HRP-conjugated Ab (SC-2768) were provided by Santa Cruz Biotechnology, (Dallas, USA). NaBu were purchased from Sigma-Aldrich, (St. Louis, USA).

\section{GC cell lines}

EPG 85-257 GC cells were kindly provided by Wroclaw Medical University, Poland and HGC-27 GC cells were purchased from CLS Cell Lines Service, (Eppelheim, Germany). EPG 85-257 and HGC-27 GC cells were respectively cultured in DMEM and DMEM/F12 growth media (Sigma-Aldrich, St. Louis, USA), supplemented with 10\% heat-inactivated fetal bovine serum (FBS), 
(Sigma-Aldrich, St. Louis, USA) and 2mM glutamine. MCF7 breast cancer cells were used as a positive control for AKR1C3 transcript and protein identification.

\section{EPG 85-257 and HGC-27 GC cell lines treatment with NaBu}

Prior to all experiments, cells were maintained for 24 hours in an appropriate phenol red-free medium, (Sigma-Aldrich, St. Louis, USA) supplemented with 5\% charcoal-dextran-stripped FBS, (Sigma-Aldrich, St. Louis, USA). To study the effect of NaBu on the HGC-27 and EPG 85-257 GC cells proliferation and viability as well as on the AKR1C3 protein level, cells were cultured for 24,48 and 72 hours in appropriate phenol red-free medium, supplemented with $5 \%$ charcoaldextran-stripped FBS, either in the absence or in the presence of $\mathrm{NaBu}$ at the concentrations of 2.0, 5.0 and 8.0mM for EPG 85-257 and 0.5, 1.5 and 3.0mM for HGC-27 GC cells. The same conditions were used to evaluate the effect of $\mathrm{NaBu}$ on $A K R 1 C 3$ transcript level in those cell lines, however incubation time was restricted to 72 hours. Growth media were replaced after every 24 hours of incubation.

Proliferation and viability assaying of the EPG 85-257 and HGC-27 GC cells after NaBu treatment After respective time of incubation, the cells were harvested and total number of viable and dead cells were counted with trypan blue dye. Total cells number, stained and unstained, was represented as a percent of respective control for proliferation assay. Cells viability was calculated with using following equation: total viable cells (unstained)/total cells (stained and ustained) $\mathrm{x} 100$ and represented as a percent of respective control. Each sample was determined in triplicate and results are presented as the mean $\pm \mathrm{SD}$ from three experiments

Reverse transcription and real-time quantitative polymerase chain reaction (RQ-PCR) analysis of the AKR1C3 transcript levels

The total RNA from the primary tissue of patients with GC as well as from EPG 85-257 and HGC-27 GC cells was isolated according to the method of Chomczyński and Sacchi (2006). Purity and integrity of RNA was assessed with using Nano-100 spectrophotometer (Hangzhou Allsheng, China) 
and gel electrophoresis respectively. RNA samples were treated with DNase I, quantified, and reversetranscribed into cDNA. RQ-PCR was carried out in a Light Cycler real-time PCR detection system from Roche Diagnostics GmbH, (Mannheim, Germany) using SYBR ${ }^{\circledR}$ Green I as detection dye. The transcript levels in patient tissues were expressed as multiplicity of these cDNA concentrations in the calibrator. In EPG 85-257 and HGC-27 GC cells, these transcript levels were presented as multiplicity of the respective controls. The calibrator was prepared as cDNA mix from all of the patient samples and successive dilutions were used to create the standard curve as is described in Relative Quantification Manual Roche Diagnostics GmbH, (Mannheim, Germany). For amplification, $1 \mu \mathrm{l}$ of cDNA solution was added to $9 \mu \mathrm{l}$ of Light Cycler ${ }^{\circledR} 480$ SYBR Green I Master mix (Roche, Mannheim, Germany) contained the following primers sequences: AKR1C3 forward:

5'-GGGATCTCAACGAGACAAAC-3' and reverse: 5'-AAAGGACTGGGTCCTCCAAG-3'. The quantity of $A K R 1 C 3$ transcripts in each sample was standardized by the geometric mean of beta-2-microglobulin (B2M) and beta-glucuronidase (GUSB) cDNA levels and expressed as multiples of these cDNA in the calibrator.

\section{Western blotting analysis}

The tissue of patients as well as EPG 85-257 and HGC-27 GC cells were treated with lysis RIPA buffer for proteins isolation. Then, $40 \mu \mathrm{g}$ of protein were resuspended in sample buffer and separated on $12 \%$ Tris-glycine gel using sodium dodecyl sulfate-polyacrylamide gel electrophoresis (SDSPAGE). Gel proteins were transferred to nitrocellulose membrane, which was next blocked with $5 \%$ milk in Tris/ $\mathrm{HCl}$ saline/Tween buffer. Immunodetection of the bands was performed with goat polyclonal anti-AKR1C3 Ab, followed by incubation with rabbit anti-goat HRP-conjugated Ab. To ensure equal protein loading of the lanes, the membrane was re-stripped and incubated with rabbit polyclonal anti-GAPDH Ab and goat anti-rabbit HRP-conjugated Ab. Bands were revealed using ECL kit and Hyperfilm ECL Amersham (Piscataway, NJ). The amount of AKR1C3 protein was calculated as the AKR1C3 to GAPDH band optical density ratio. 


\section{Statistical analysis}

Normality of the observed patient data distribution was assessed by Shapiro-Wilk test, followed by unpaired, two-tailed t-test or Mann-Whitney test to consider statistically significant differences of compared mean values. Data groups for cell lines were assessed by ANOVA to evaluate if there was significance $(p<0.05)$ between the groups. For the all experimental groups, which fulfilled the initial criterion, individual comparisons were performed by post hoc Tukey test with the assumption of twotailed distribution and two samples with equal variance at the $\mathrm{p}<0.05$ level. Statistical analysis was performed using STATISTICA 10 software. 
Results

Transcript and protein levels of AKRIC3 in nontumoral and primary tumoral tissues from patients with $G C$

We found significantly lower levels of $A K R 1 C 3$ transcript $(\mathrm{p}<0.0001)$ in primary tumoral as compared to adjacent histopathologically normal appearing mucosa of patients with GC (Tab. 2, Fig. 1A), regardless of analysed histopatological features. Moreover, we observed significantly lower levels of $A K R 1 C 3$ transcript in diffuse $(\mathrm{p}=0.0003)$ and intestinal $(\mathrm{p}<0.0001)$, but not in the indeterminated histological types of GC. In case of body, fundus, lesser curvature and pylorus GC localization, in T1 grade of tumor depth, M1 grade of distant metastases and G1 histological tumor grade, we not observed significantly lower levels of $A K R 1 C 3$ transcript in primary tumoral tissues, probably due to not sufficient cases number. Tissue from the same patients were also used for determination of AKR1C3 protein level (Tab. 3, Fig. 1B). Unfortunately in two cases, amount of the material was not sufficient for western blot analysis. However, we found lower levels of AKR1C3 protein in primary tumoral than in adjacent histopathologically normal appearing mucosa tissues of patients with $\mathrm{GC}(\mathrm{p}=0.0021)$. The difference in protein level among those types of tissue was small despite the statistical significance. Protein levels of AKR1C3 in primary tumoral tissues were decreased regardless of age and gender, however we observed significantly lower levels of AKR1C3 protein in tumors with multi site localization $(p=0.0051)$, in diffuse histological type $(p=0.025), T 3(p=0.015)$ and T4 $(p=0.048)$ grade of tumor depth as well as in $\mathrm{G} 3(\mathrm{p}=0.0013)$ histological grading. In case of GC localization, tumor depth and distant metastases we could not observed significantly lower AKR1C3 protein levels probably, due to small number of patients.

\section{Effect of NaBu on the proliferation and viability of EPG 85-257 and HGC-27 GC cells}

$\mathrm{NaBu}$ significantly inhibited the proliferation (Fig. 2) of both EPG 85-257 (A) and HGC-27 (C) GC cells at the all incubations time and used doses, except, EPG 85-257 cells cultured for 24 hours in presence of $2.0 \mathrm{mM}(\mathrm{p}=0.9)$ and $5.0 \mathrm{mM}(\mathrm{p}=0.55)$ of $\mathrm{NaBu}$ concentrations. Simultaneously, $\mathrm{NaBu}$ 
significantly decreased EPG $85-257$ cells viability (B) at dose of $8.0 \mathrm{mM}$ incubated for 72 hours $(\mathrm{p}=0.0072)$. In case of HGC-27 cells (D), significant decrease of viability was observed after 48 and 72 hours of incubation with the presence of $\mathrm{NaBu}$ at the concentrations of $0.5,1.5$ and $3.0 \mathrm{mM}$.

Effect of NaBu on AKR1C3 transcript and protein levels in EPG 85-257 and HGC-27 GC cells

We were able to detect AKR1C3 protein which was confirmed by positive control- MCF7 protein lysate. However, we also observed an unspecific protein band above AKR1C3 band in some tissues and GC cell lines. This unspecific signal was not analyzed. We observed increase of $A K R 1 C 3$ transcript (Fig. 3) in EPG 85-257 (A) and HGC-27 (B) GC cells after 72 hours of incubation with $\mathrm{NaBu}$ at the concentrations of $2.0,5.0,8.0 \mathrm{mM}$ and $0.5,1.5,3.0 \mathrm{mM}$ respectively. The best effect in the increase of transcript level in EPG 85-257 cells were observed after incubation with $5.0 \mathrm{mM}$ and $8.0 \mathrm{mM}(\mathrm{p}<0.001)$ of $\mathrm{NaBu}$. In case of HGC-27 cells all used doses were sufficient for significantly increase of AKR1C3 transcript level $(\mathrm{p}<0.01)$. Protein bands of AKR1C3 in EPG 85-257 (Fig. 4A) cells were only observed due to 48 and 72 hours incubation at presence of $8 \mathrm{mM}$ $\mathrm{NaBu}$. In HGC-27 (Fig. 4B) cells we observed significantly increased in AKR1C3 protein bands density in all $\mathrm{NaBu}$ treated samples according to 24-72 hours of incubation. 
Discussion

Local steroidogenesis driven by steroidogenic enzymes is an important source of androgens and estrogens in peripheral tissues and could have significant meaning in cancer development (Brodie et al. 2009). Our work showed reduced transcript and protein levels of AKR1C3 in primary tumoral tissues of fifty five patients with diagnosed GC. Strong positive AKR1C3 immunohistochemical staining was previously demonstrated in nontumoral gastric tissues and positive AKR1C3 staining was shown in 59\% of gastric tumoral tissues (Guise et al. 2010). Strong AKR1C3 positive immunoreactivity was also demonstrated in the nontumoral gastric mucosal cells, lining close to the luminal surface but no or weak immunoreactivity was presented in deeply located epithelial cells such as those in the gastric pits (Chang et al. 2013).

Since we used homogenized control mucosa containing both types of these cells, our results could be limited by the method we used. Moreover, in contrast to the previous results, the same study showed strong AKR1C3 positive immunoreactivity in GC tissues. On the other hand, this study was limited by relative small number of examined cases (9 gastric adenocarcinomas). Immunoreactivity of AKR1C3 in tumoral gastric tissues was also demonstrated by Nakamura et al. (2006). However, due to simultaneous presence of this enzyme in nontumoral adjacent mucosa, authors suspected limited AKR1C3 contribution to the development of GC. Up-regulation of AKR1C3 transcript and protein levels were widely shown in breast (Lin et al. 2004; Vihko et al. 2005; Jansson et al. 2006; Suzuki et al. 2007) and prostate (Fung et al. 2006; Stanbrough et al. 2006; Locke et al. 2008; Wako et al. 2008; Pfeiffer et al. 2011; Hamid et al. 2013) tumoral tissues which are known to be steroid sensitive. Thus an over-expression of AKR1C3 could facilitate the growth of those tumors by increasing the intratissue level of active steroids. Additionally, LNCaP prostate cancer cells with AKR1C3 over-expression were shown to synthesize higher amounts of T which results an increased of their proliferation rate (Byrns et al. 2012).

In our study, we showed that decreased $A K R 1 C 3$ transcript levels were significantly associated with diffuse and intestinal type of GC. Lowered AKR1C3 protein levels were also significantly correlated with multi site localization, diffuse histological type, T3 and T4 grades of tumor depth and G3, 
histological grading. Higher amounts of $A K R I C 3$ transcript was found in bone metastases in comparison with non-malignant or malignant prostate tissue (Jernberg et al. 2013). An up-regulation of AKR1C3 transcript and protein levels was also observed in breast cancer and was associated with poor prognosis of patients (Lin 2004; Jansson et al. 2006; Vihko 2006; Suzuki et al. 2007).

AKR1C3 is responsible for both, a-dione conversion to T and E1 to E2 (Penning et al. 2000) thus its down-regulation can result in the reduction of intratissue concentration of biologically potent steroids. Since T and E2 receptors are found in both nontumoral and tumoral gastric tissues (Gan et al. 2012), steroid synthesis mediated by AKR1C3 could be significant for GC development. Moreover, epidemiological and experimental studies show estrogens, including E2, as protective agents in GC etiology (Freedman et al. 2007; Camargo et al. 2011). Additionally, in our previous study we presented that GC cells are able to convert E1 into E2 by HSD17B1 action (Frycz et al. 2013). On the other hand, the role of androgens during gastric carcinogenesis still remains unknown. However, there are studies suggesting an oncogenic potential of androgens in GC (Nakamura et al. 2006; Tian et al. 2013). In our recent work, we showed that the amount of HSD17B2 protein, which acts in opposite to AKR1C3, is also reduced in tumoral tissues of patients with GC (Frycz et al. 2015). The decreased expression of HSD17B2 could results in an elevation of E2 and T in tumoral gastric tissues. Thus, an inhibition of E1 to E2 conversion by down-regulation of AKR1C3 and an elevation of $\mathrm{T}$ level in tumoral tissue maintained by HSD17B2 down-regulation can enhance gastric carcinogenesis. Although, T synthesis can be also mediated by AKR1C3 enzyme, in vitro studies showed, that MCF7 breast cancer cells with stabled AKR1C3 expression presented increased steroid conversion leading to pro-estrogenic state and surprisingly, E1 was revealed to be reduced faster than other substrates, including a-dione (Byrns et al. 2009). Moreover, AKR1C3 posses reductive activity which partly inactivates $5 \alpha$-dihydrotestosterone (DHT), the most biologically potent androgen, to the weak androgens $3 \alpha$-androstanediol and $3 \beta$-androstanediol ( Steckelbroeck et al. 2003). Thus, tissues substrate specify of this enzyme must be clarified for better understanding of its involvement in GC development. Notably, T can be converted into E2 through aromatase (CYP19) enzyme which is known to be expressed in nontumoral and tumoral gastric mucosa (Izawa et al. 2008). The aberrant action of steroidogenic enzymes in tumoral tissues, reasulting in alterations 
of E2/T ratio, could be also caused by the presence of single nucleotide polymorphisms (SNPs) in the sequences of their genes (Rossi et al. 2003). As an example, some SNPs of CYP19 were significantly associated with increased risk of GC (Cho et al. 2012). So far, we don't know any data showing the association of $A K R 1 C 3$ polymorphism with GC risk. However, such correlation was showed in prostate cancer (Schulze et al. 2012).

Except its role in steroid conversion, AKR1C3 enzyme is able to synthesize prostaglandin F by the conversion of prostaglandin $\mathrm{H} 2$ to prostaglandin $\mathrm{F} 2 \alpha$ (PGF2 $\alpha$ ) and prostaglandin D2 to $9 \alpha, 11 \beta$-prostaglandin F2 (Matsuura et al. 1998; Suzuki-Yamamoto et al. 1999). Nakamura et al. (1989) observed significantly inhibited the growth of cultured human GC cells KATO III in dosedependent manner via stimulation of cyclic AMP production. Additionally, the percentage level of PGF2 $\alpha$ was higher in the metastatic hepatic cells as compared with cells from primary gastric lesions (Nakazawa et al. 1993). Moreover, an elevated PGF2 $\alpha$ protein level in breast cancer patients was correlated with good prognosis (Vergote et al. 1985). High levels of PGF2 $\alpha$ were also positively associated with differentiation, positive estrogen and progestagen receptor status, as well as low mitotic index. Thus, disturbances in the level of PGF2 $\alpha$, mediated by the altered AKR1C3 expression could be significant for gastric carcinogenesis, however this must be further clarified.

In our work, we evaluated the influence of HDAC inhibitor - NaBu, on the AKR1C3 expression level in EPG 85-257 and HGC-27 GC cells. We also investigated its impact on the cell viability and proliferation. Histones acetylation and deacetylation are important processes involved in the regulation of gene expression (Ropero and Esteller 2007). Since altered expression of genes encoding HDAC has been associated with the development of many tumors, including GC (Choi et al. 2001; Song et al. 2005), they become promising targets for cancer therapy (Ropero and Esteller 2007). The potent anti-tumor activity of $\mathrm{NaBu}$ was presented in numerous studies, employing various cell lines, what makes that chemical a potentially useful agent in cancer therapy, including GC (Medina et al. 1997; Richon et al. 1998; Shin et al. 2012). It was shown, that $\mathrm{NaBu}$ activates the cell cycle inhibitors like p21Waf1/Cip1 and p27Kip1 as well as proapoptotic factors including Bax, Bak and Bik, therefore it induces growth arrest and apoptosis in the human SIIA GC cells (Litvak et al. 2000). Additionally, NaBu treatment of AGS, KATO III, MKN28, MKN45, MKN74, NCI-N87, 
SNU1, SNU16 and SNU638 GC cells caused up-regulation of death-associated protein kinase 1/2 but also down-regulation of focal adhesion kinase protein and finally, leaded to cells apoptosis (Shin et al. 2012). Similarly, in our study $\mathrm{NaBu}$ significantly decreased proliferation and viability of both, EPG 85-257 and HGC-27 GC cells in dose and time dependent manner. The decreased proliferation and viability of $\mathrm{HGC}-27 \mathrm{GC}$ cells, caused by $\mathrm{NaBu}$ mediated increase in phosphatase and tensin homolog expression, was previously shown by Pan et al. (2010). We also demonstrated, that $\mathrm{NaBu}$ is able to up-regulate transcript and protein of AKR1C3 in EPG 85-257 and HGC-27 GC cells. To the best of our knowledge, there are no studies which have shown the regulation of AKR1C3 by $\mathrm{NaBu}$, however this compound was able to influence the expression of other genes involved in steroidogenesis. The $\mathrm{NaBu}$ mediated up-regulation of HSD17B1 mRNA and protein levels was observed in colorectal cancer cell lines - HT29 and SW707 (Rawłuszko et al. 2011). This led to an increased conversion of E1 to E2 in investigated cells. Thus, the intratissue concentration of steroid hormones could be modified by HDAC inhibitors (Martinez-Arguelles and Papadopoulos 2010).

Altogether, we showed reduced expression of AKR1C3 in a group of patients with diagnosed GC as well as in EPG 85-257 and HGC-27 GC cell lines. Along with emerging role of steroid enzymes in GC etiology, an alteration in intratissue synthesis of active steroids mediated by AKR1C3 down-regulation could be significant for the development of this cancer. Lowered transcript and protein levels of AKR1C3 were significantly associated with some clinicopathological features in GC. Moreover, we showed that the expression of AKR1C3 in GC cells could be restored by $\mathrm{NaBu}$ activity. Additionally, GC cells treated with $\mathrm{NaBu}$ were characterized by reduced proliferation rate and viability. With better understanding the role of AKR1C3 in GC etiology these observations could be helpful for new treatment strategies. Our studies are limited by relatively small patients group, so we are unable to explain what is an exact role of AKR1C3 expression in GC development. We also used homogenized tissues in our studies, therefore we can't exclude the possibility of samples contamination with other cell types like fibroblasts, endothelial cells, smooth muscle or blood cells. Moreover, synthesis of steroid hormones in gastric tissue could be regulated by expression of other genes involved in steroidogenesis process, thus next studies are needed. 
Acknowledgements

Supported by grant No 502-14-01124182-09811 and 502-01-01118170-05274, Poznań University of Medical Sciences.

References

Brodie, A., Njar, V., Macedo, L.F., Vasaitis, T.S., and Sabnis, G. 2009. The Coffey Lecture: steroidogenic enzyme inhibitors and hormone dependent cancer. Urol. Oncol. 27(1): 53-63. doi:10.1016/j.urolonc.2008.07.036. PMID:19111799.

Byrns, M.C., Duan, L., Lee, S.H., Blair, I.A., and Penning, T.M. 2009. Aldo-keto reductase 1C3 expression in MCF-7 cells reveals roles in steroid hormone and prostaglandin metabolism that may explain its over-expression in breast cancer. J. Steroid Biochem. Mol. Biol. 118(3): 177-87. doi:10.1016/j.jsbmb.2009.12.009. PMID:20036328.

Byrns, M.C., Mindnich, R., Duan, L., and Penning, T.M. 2012. Overexpression of aldo-keto reductase 1C3 (AKR1C3) in LNCaP cells diverts androgen metabolism towards testosterone resulting in resistance to the $5 \alpha$-reductase inhibitor finasteride. J. Steroid Biochem. Mol. Biol. 130(1-2): 7-15. doi:10.1016/j.jsbmb.2011.12.012. PMID:22265960.

Camargo, M.C., Goto, Y., Zabaleta, J., Morgan, D.R., Correa, P., and Rabkin, C.S. 2011. Sex hormones, hormonal interventions, and gastric cancer risk: a meta-analysis. Cancer Epidemiol. Biomarkers Prev. 21(1): 20-38. doi:10.1158/1055-9965. PMID:22028402.

Chandanos, E., Lindblad, M., Rubio, C.A., Jia, C., Warner, M., Gustafsson, J.A., and Lagergren, J. 2008. Tamoxifen exposure in relation to gastric adenocarcinoma development. Eur. J. Cancer. 44(7): 1007-14. doi:10.1016/j.ejca.2008.02.049. PMID:18394879.

Chang, T.S., Lin, H.K., Rogers, K.A., Brame, L.S., Yeh, M.M., Yang, Q., and Fung, K.M. 2013. Expression of aldo-keto reductase family 1 member C3 (AKR1C3) in neuroendocrine tumors \& 
adenocarcinomas of pancreas, gastrointestinal tract, and lung. Int. J. Clin. Exp. Pathol. 6(11): 2419-29. PMID:24228104.

Cho, L.Y., Yang, J.J., Ko, K.P., Ma, S.H., Shin, A., Choi, B.Y., Han, D.S., et al. 2012. Genetic susceptibility factors on genes involved in the steroid hormone biosynthesis pathway and progesterone receptor for gastric cancer risk. PLoS One. 7(10):e47603. doi:10.1371/journal.pone.0047603. PMID:23110082.

Choi, J.H., Kwon, H.J., Yoon, B.I., Kim, J.H., Han, S.U., Joo, H.J., and Kim, D.Y. 2001. Expression profile of histone deacetylase 1 in gastric cancer tissues. Jpn. J. Cancer Res. 92(12): 1300-4. PMID:11749695.

Chomczynski, P., and Sacchi, N. 2006. The single-step method of RNA isolation by acid guanidinium thiocyanate-phenol-chloroform extraction: twenty-something years on. Nat. Protoc. 1(2): 581-5. PMID:17406285.

Dozmorov, M.G., Azzarello, J.T., Wren, J.D., Fung, K.M., Yang, Q., Davis, J.S., et al. 2010. Elevated AKR1C3 expression promotes prostate cancer cell survival and prostate cell-mediated endothelial cell tube formation: implications for prostate cancer progression. BMC Cancer, 6;10:672. doi:10.1186/1471-2407-10-672. PMID:21134280.

Drzewiecka, H., Gałęcki, B., Jarmołowska-Jurczyszyn, D., Kluk, A., Dyszkiewicz, W., and Jagodziński, P.P. 2015. Increased expression of 17-beta-hydroxysteroid dehydrogenase type 1 in non-small cell lung cancer. Lung Cancer, 87(2): 107-16. doi:10.1016/j.lungcan.2014.12.012. PMID:25564397.

Frycz, B.A., Murawa, D., Wysocki-Borejsza, M., Marciniak, R., Murawa, P., Drews, M., and Jagodziński, P.P. 2013. Expression of 17ß-hydroxysteroid dehydrogenase type 1 in gastric cancer. Biomed. Pharmacother. 67(7): 651-7. doi:10.1016/j.biopha.2013.06.012. PMID:23916544.

Frycz, B.A., Murawa, D., Borejsza-Wysocki, M., Marciniak, R., Murawa, P., Drews, M., and Jagodziński, P.P. 2015. Expression of 17ß-hydroxysteroid dehydrogenase type 2 is associated with 
some clinicopathological features in gastric cancer. Biomed. Pharmacother. 70:24-7. doi:10.1016/j.biopha.2014.12.042. PMID:25776474.

Fung, K.M., Samara, E.N., Wong, C., Metwalli, A., Krlin, R., Bane, B., Liu, C.Z., et al. 2006. Increased expression of type 2 3alpha-hydroxysteroid dehydrogenase/type 5 17beta-hydroxysteroid dehydrogenase (AKR1C3) and its relationship with androgen receptor in prostate carcinoma. Endocr. Relat. Cancer. 13(1): 169-80. PMID:16601286.

Gan, L., He, J., Zhang, X., Zhang, Y.J., Yu, G.Z., Chen, Y., et al. 2012. Expression profile and prognostic role of sex hormone receptors in gastric cancer. BMC Cancer, 2;12:566. doi:10.1186/1471-2407-12-566. PMID:23199240.

Gianfrilli, D., Pierotti, S., Pofi, R., Leonardo, C., Ciccariello, M., and Barbagallo, F. 2014. Sex steroid metabolism in benign and malignant intact prostate biopsies: individual profiling of prostate intracrinology. Biomed. Res. Int. 2014:464869. doi:10.1155/2014/464869. PMID:25184140.

Guise, C.P., Abbattista, M.R., Singleton, R.S., Holford, S.D., Connolly, J., Dachs, G.U., Fox, S.B., et al. 2010. The bioreductive prodrug PR-104A is activated under aerobic conditions by human aldoketo reductase 1C3. Cancer Res. 70(4): 1573-84. doi:10.1158/0008-5472.CAN-09-3237. PMID:20145130.

Hamid, A.R., Pfeiffer, M.J., Verhaegh, G.W., Schaafsma, E., Brandt, A., Sweep, F.C., Sedelaar, J.P., and Schalken, J.A. 2013. Aldo-keto reductase family 1 member C3 (AKR1C3) is a biomarker and therapeutic target for castration-resistant prostate cancer. Mol. Med. 22;18: 1449-55. doi:10.2119/molmed.2012.00296. PMID:23196782.

Izawa, M., Inoue, M., Osaki, M., Ito, H., Harada, T., Terakawa, N., and Ikeguchi, M. 2008. Cytochrome P450 aromatase gene (CYP19) expression in gastric cancer. Gastric Cancer. 11(2):10310. doi:10.1007/s10120-008-0463-x. PMID:18595017. 
Jansson, A.K., Gunnarsson, C., Cohen, M., Sivik, T., and Stål, O. 2006. 17beta-hydroxysteroid dehydrogenase 14 affects estradiol levels in breast cancer cells and is a prognostic marker in estrogen receptor-positive breast cancer. Cancer Res. 66(23):11471-7. PMID:17145895.

Jemal, A., Bray, F., Center, M.M., Ferlay, J., Ward, E., and Forman D. 2011. Global cancer statistics. CA Cancer J. Clin. 61(2): 69-90. doi:10.3322/caac.20107. PMID:21296855.

Jernberg, E., Thysell, E., Bovinder Ylitalo, E., Rudolfsson, S., Crnalic, S., Widmark, A., Bergh, A., and Wikström, P. 2013. Characterization of prostate cancer bone metastases according to expression levels of steroidogenic enzymes and androgen receptor splice variants. PLoS One, 8(11):e77407. doi:10.1371/journal.pone.0077407. PMID:24244276.

Labrie, F., Luu-The, V., Lin, S.X., Simard, J., Labrie, C., El-Alfy, M., Pelletier, G., and Bélanger, A. 2000. Intracrinology: role of the family of 17 beta-hydroxysteroid dehydrogenases in human physiology and disease. J. Mol. Endocrinol. 25(1): 1-16. PMID:10915214.

Labrie, F., and Labrie, C. 2013. DHEA and intracrinology at menopause, a positive choice for evolution of the human species. Climacteric. 16(2): 205-13. doi:10.3109/13697137.2012.733983. PMID:23126249.

Lee, Y.Y., and Derakhshan, M.H. 2013. Environmental and lifestyle risk factors of gastric cancer. Arch. Iran Med. 16(6): 358-65. doi:013166/AIM.0010. PMID:23725070.

Lewis, M.J., Wiebe, J.P., and Heathcote, J.G. 2004. Expression of progesterone metabolizing enzyme genes (AKR1C1, AKR1C2, AKR1C3, SRD5A1, SRD5A2) is altered in human breast carcinoma. BMC Cancer, 22;4:27. PMID:15212687.

Lin, J.H., and Giovannucci, E. 2010. Sex hormones and colorectal cancer: what have we learned so far? J. Natl. Cancer Inst. 102(23): 1746-7. doi:10.1093/jnci/djq444. PMID:21068431.

Lin, H.K., Steckelbroeck, S., Fung, K.M., Jones, A.N., and Penning, T.M. 2004. Characterization of a monoclonal antibody for human aldo-keto reductase AKR1C3 (type 2 3alpha-hydroxysteroid 
dehydrogenase/type 5 17beta-hydroxysteroid dehydrogenase); immunohistochemical detection in breast and prostate. Steroids, 69(13-14): 795-801. PMID:15582534.

Litvak, D.A., Hwang, K.O., Evers, B.M., and Townsend C.M. 2000. Induction of apoptosis in human gastric cancer by sodium butyrate. Anticancer Res. 20(2A):779-84. PMID:10810354.

Locke, J.A., Guns, E.S., Lubik, A.A., Adomat, H.H., Hendy, S.C., Wood, C.A., et al. 2008. Androgen levels increase by intratumoral de novo steroidogenesis during progression of castration-resistant prostate cancer. Cancer Res. 68(15): 6407-15. doi:10.1158/0008-5472.CAN-07-5997. PMID:18676866.

Martinez, I., Wang, J., Hobson, K.F., Ferris, R.L., and Khan, S.A. 2007. Identification of differentially expressed genes in HPV-positive and HPV-negative oropharyngeal squamous cell carcinomas. Eur. J. Cancer. 43(2): 415-32. PMID:17079134.

Martinez-Arguelles, D.B., and Papadopoulos, V. 2010. Epigenetic regulation of the expression of genes involved in steroid hormone biosynthesis and action. Steroids, 75(7): 467-76. doi:10.1016/j.steroids.2010.02.004. PMID:20156469.

Matsuura, K., Shiraishi, H., Hara, A., Sato, K., Deyashiki, Y., Ninomiya, M., and Sakai S. 1998. Identification of a principal mRNA species for human 3alpha-hydroxysteroid dehydrogenase isoform (AKR1C3) that exhibits high prostaglandin D2 11-ketoreductase activity. J. Biochem. 124(5): 940-6. PMID:9792917.

Medina, V., Edmonds, B., Young, G.P., James, R., Appleton, S., and Zalewski P.D. 1997. Induction of caspase-3 protease activity and apoptosis by butyrate and trichostatin A (inhibitors of histone deacetylase): dependence on protein synthesis and synergy with a mitochondrial/cytochrome c-dependent pathway. Cancer Res. 57(17): 3697-707. PMID:9288776.

Moeller, G., and Adamski, J. 2009. Integrated view on 17beta-hydroxysteroid dehydrogenases. Mol. Cell Endocrinol. 301(1-2): 7-19. doi:10.1016/j.mce.2008.10.040. PMID:19027824. 
Mungenast, F., and Thalhammer, T. 2014. Estrogen biosynthesis and action in ovarian cancer. Front. Endocrinol. (Lausanne). 12;5:192. doi:10.3389/fendo.2014.00192. PMID:25429284.

Nakamura, A., Chiba, T., Yamatani, T., Yamaguchi, A., Inui, T., Morishita, T., Kadowaki, S., and Fujita, T. 1989. Prostaglandin E2 and F2 alpha inhibit growth of human gastric carcinoma cell line KATO III with simultaneous stimulation of cyclic AMP production. Life Sci. 44(1): 75-80. PMID:2536452.

Nakamura, Y., Shimada, N., Suzuki, T., Imatani, A., Sekine, H., Ohara, S., Shimosegawa, T., and Sasano, H. 2006. In situ androgen production in human gastric carcinoma--androgen synthesizing and metabolizing enzymes. Anticancer Res. 26(3A): 1935-9. PMID:16827127.

Nakazawa, I., Iwaizumi, M., and Ohuchi, K. 1993. Some features of prostaglandin synthesis of the cancer cells metastasized into liver from gastric cancer lesions. Tohoku J. Exp. Med. 170(1): 5961. PMID:8278990.

Pan, L., Matloob, A.F., Du, J., Pan, H., Dong, Z., Zhao, J., Feng, Y., and et al. 2010. Vitamin D stimulates apoptosis in gastric cancer cells in synergy with trichostatin A /sodium butyrate-induced and 5-aza-2'-deoxycytidine-induced PTEN upregulation. FEBS J. 277(4): 989-99. doi:10.1111/j.17424658.2009.07542.x. PMID:20089040.

Park, A.L., Lin, H.K., Yang, Q., Sing, C.W., Fan, M., Mapstone, T.B., Gross, N.L., et al. 2010. Differential expression of type $23 \alpha$ /type $517 \beta$-hydroxysteroid dehydrogenase (AKR1C3) in tumors of the central nervous system. Int. J. Clin. Exp. Pathol. 3(8): 743-54. PMID:21151387.

Penning, T.M., Burczynski, M.E., Jez, J.M., Hung, C.F., Lin, H.K., Ma, H., et al. 2000. Human 3alpha-hydroxysteroid dehydrogenase isoforms (AKR1C1-AKR1C4) of the aldo-keto reductase superfamily: functional plasticity and tissue distribution reveals roles in the inactivation and formation of male and female sex hormones. Biochem. J. 351(Pt 1): 67-77. PMID:10998348. 
Pfeiffer, M.J., Smit, F.P., Sedelaar, J.P., and Schalken, J.A. 2011. Steroidogenic enzymes and stem cell markers are upregulated during androgen deprivation in prostate cancer. Mol. Med. 17(7-8): 65764. doi:10.2119/molmed.2010.00143. PMID:21365123.

Polimeno, L., Silecchia, G., Spaziani, E., Scucchi, A., Dell'Aquila, P., Ierardi, E., et al. 1994. Estrogens, androgens, and EGF receptor expression in gastric carcinoma induced by N-methyl-N'nitro-N-nitrosoguanidine. Dig. Dis. Sci. 39(3): 635-40. PMID:8131702.

Rahbari, R., Zhang, L., and Kebebew, E. 2010. Thyroid cancer gender disparity. Future Oncol. 6(11): 1771-9. doi:10.2217/fon.10.127. PMID:21142662.

Rawłuszko, A.A., Krokowicz, P., and Jagodziński, P.P. 2011. Butyrate induces expression of 17ß-hydroxysteroid dehydrogenase type 1 in HT29 and SW707 colorectal cancer cells. DNA Cell Biol. 30(9): 661-9. doi:10.1089/dna.2010.1192. PMID:21563966.

Richon, V.M., Emiliani, S., Verdin, E., Webb, Y., Breslow, R., Rifkind, R.A., and Marks, P.A. 1998. A class of hybrid polar inducers of transformed cell differentiation inhibits histone deacetylases. Proc. Natl. Acad. Sci. USA. 95(6): 3003-7. PMID:9501205.

Ropero, S., and Esteller, M. 2007. The role of histone deacetylases (HDACs) in human cancer. Mol. Oncol. 1(1): 19-25. doi:10.1016/j.molonc.2007.01.001. PMID:19383284.

Rossi, L., Leveri, M., Gritti, C., De Silvestri, A., Zavaglia, C., Sonzogni, L., et al. 2003. Genetic polymorphisms of steroid hormone metabolizing enzymes and risk of liver cancer in hepatitis Cinfected patients. J. Hepatol. 39(4): 564-70. PMID:12971967.

Sasano, H., Suzuki, T., and Harada, N. 1998. From Endocrinology to Intracrinology. Endocr. Pathol. 9(1):9-20. PMID:12114657.

Sasano, H., Suzuki, T., Nakata, T., and Moriya, T. 2006. New development in intracrinology of breast carcinoma. Breast Cancer. 13(2): 129-36. PMID:16755106. 
Sasano, H., Suzuki, T., Takeyama, J., Utsunomiya, H., Ito, K., Ariga, N., and Moriya T. 2000. 17-beta-hydroxysteroid dehydrogenase in human breast and endometrial carcinoma. A new development in intracrinology. Oncology. 59(1): 5-12. PMID:11096350.

Schulze, J.J., Karypidis, H., and Ekström, L. 2012. Basal and Regulatory Promoter Studies of the AKR1C3 Gene in Relation to Prostate Cancer. Front. Pharmacol. 6;3:151. doi:10.3389/fphar.2012.00151. PMID:22888320.

Shin, H., Kim, J.H., Lee, Y.S., and Lee, Y.C. 2012. Change in gene expression profiles of secreted frizzled-related proteins (SFRPs) by sodium butyrate in gastric cancers: induction of promoter demethylation and histone modification causing inhibition of Wnt signaling. Int. J. Oncol. 40(5): 1533-42. doi:10.3892/ijo.2012.1327. PMID:22246241.

Shin, H., Lee, Y.S., and Lee, Y.C. 2012. Sodium butyrate-induced DAPK-mediated apoptosis in human gastric cancer cells. Oncol. Rep. 27(4): 1111-5. doi:10.3892/or.2011.1585. PMID:22160140.

Song, J., Noh, J.H., Lee, J.H., Eun, J.W., Ahn, Y.M., Kim, S.Y., Lee, S.H., et al. 2005. Increased expression of histone deacetylase 2 is found in human gastric cancer. APMIS. 113(4): 264-8. PMID:15865607.

Stanbrough, M., Bubley, G.J., Ross, K., Golub, T.R., Rubin, M.A., Penning, T.M., et al. 2006. Increased expression of genes converting adrenal androgens to testosterone in androgen-independent prostate cancer. Cancer Res. 66(5): 2815-25. PMID:16510604.

Steckelbroeck, S., Jin, Y., Gopishetty, S., Oyesanmi, B., and Penning, T.M. 2003. Human cytosolic 3alpha-hydroxysteroid dehydrogenases of the aldo-keto reductase superfamily display significant 3beta-hydroxysteroid dehydrogenase activity: implications for steroid hormone metabolism and action. J. Biol. Chem. 279(11): 10784-95. PMID:14672942.

Suzuki, T., Miki, Y., Moriya, T., Akahira, J., Hirakawa, H., Ohuchi, N., and Sasano, H. 2007. In situ production of sex steroids in human breast carcinoma. Med. Mol. Morphol. 40(3): 121-7. PMID:17874044. 
Suzuki-Yamamoto, T., Nishizawa, M., Fukui, M., Okuda-Ashitaka, E., Nakajima, T., Ito, S., and Watanabe, K. 1999. cDNA cloning, expression and characterization of human prostaglandin F synthase. FEBS Lett. 462(3): 335-40. PMID:10622721.

Tian, Y., Wan, H., Lin, Y., Xie, X., Li, Z., and Tan, G. 2013. Androgen receptor may be responsible for gender disparity in gastric cancer. Med. Hypotheses. 80(5): 672-4. doi:10.1016/j.mehy.2013.01.023. PMID:23414681.

Vergote, I.B., Laekeman, G.M., Keersmaekers, G.H., Uyttenbroeck, F.L., Vanderheyden, J.S., Albertyn, G.P., et al. 1985. Prostaglandin F2 alpha in benign and malignant breast tumours. Br. J. Cancer. 51(6): 827-36. PMID:3859318.

Vihko, P., Herrala, A., Härkönen, P., Isomaa, V., Kaija, H., Kurkela, R., Li, Y., et al. 2005. Enzymes as modulators in malignant transformation. J. Steroid Biochem. Mol. Biol. 93(2-5): $277-83$. PMID:15860271.

Wako, K., Kawasaki, T., Yamana, K., Suzuki, K., Jiang, S., Umezu, H. Nishiyama, T., et al. 2008. Expression of androgen receptor through androgen-converting enzymes is associated with biological aggressiveness in prostate cancer. J. Clin. Pathol. 61(4): 448-54. PMID:17720776.

Zakharov, V., Lin, H.K., Azzarello, J., McMeekin, S., Moore, K.N., Penning, T.M., and Fung, K.M. 2010. Suppressed expression of type 2 3alpha/type 5 17beta-hydroxysteroid dehydrogenase (AKR1C3) in endometrial hyperplasia and carcinoma. Int. J. Clin. Exp. Pathol. 3(6):608-17. PMID:20661409. 
Tab. 1. Clinicopathological classification of GC tissue specimens.

\begin{tabular}{|c|c|}
\hline Features & No. of patients \\
\hline Total no. of patients & 55 \\
\hline Gender (male/female) & $33 / 22$ \\
\hline Mean $( \pm \mathrm{SD})$ age at radical gastric resection (years) & $68.42 \pm 8.93$ \\
\hline \multicolumn{2}{|l|}{ GC localization } \\
\hline Multi site & 37 \\
\hline Cardia & 11 \\
\hline Body & 1 \\
\hline Fundus & 1 \\
\hline Lesser curvature & 3 \\
\hline Pylorus & 2 \\
\hline \multicolumn{2}{|l|}{ Histological types } \\
\hline Diffuse & 16 \\
\hline Intestinal & 23 \\
\hline Indeterminated & 12 \\
\hline \multicolumn{2}{|l|}{ Tumor depth } \\
\hline $\mathrm{T} 1$ & 1 \\
\hline $\mathrm{T} 2$ & 9 \\
\hline T3 & 26 \\
\hline $\mathrm{T} 4$ & 16 \\
\hline \multicolumn{2}{|l|}{ Lymph nodes metastases } \\
\hline No & 15 \\
\hline N1 & 7 \\
\hline $\mathrm{N} 2$ & 15 \\
\hline N3 & 15 \\
\hline \multicolumn{2}{|l|}{ Distant metastases } \\
\hline M0 & 38 \\
\hline M1 & 4 \\
\hline \multicolumn{2}{|l|}{ Histological grading } \\
\hline G1 & 1 \\
\hline $\mathrm{G} 2$ & 14 \\
\hline G3 & 35 \\
\hline
\end{tabular}


Tab. 3. AKR1C3 protein levels in nontumoral and primary tumoral tissue samples from patients with GC.

\begin{tabular}{|c|c|c|c|c|c|c|}
\hline & & \multicolumn{2}{|c|}{ Nontumoral tissues } & \multicolumn{2}{|c|}{ Primary tumoral tissues } & \multirow[t]{2}{*}{$\mathrm{p}^{*}$} \\
\hline & & Median (range) & Mean \pm SD & Median (range) & Mean \pm SD & \\
\hline All patients & 53 & $2.931(2.349-3.343)$ & $2.934 \pm 0.15$ & $2.88 \quad(1.942-3.192)$ & $2.827 \pm 0.224$ & 0.0021 \\
\hline \multicolumn{7}{|l|}{ Age (years) } \\
\hline$\leq 65$ & 22 & $2.93 \quad(2.383-3.343)$ & $2.948 \pm 0.169$ & $2.9 \quad(1.942-3.089)$ & $2.777 \pm 0.27$ & 0.036 \\
\hline$>65$ & 31 & $2.931(2.349-3.175)$ & $2.925 \pm 0.138$ & $2.859(2.253-3.192)$ & $2.864 \pm 0.182$ & 0.026 \\
\hline \multicolumn{7}{|l|}{ Gender } \\
\hline Male & 32 & $2.932(2.349-3.175)$ & $2.938 \pm 0.134$ & $2.906(2.417-3.192)$ & $2.885 \pm 0.153$ & 0.043 \\
\hline Female & 21 & $2.923(2.383-3.343)$ & $2.929 \pm 0.175$ & $2.808(1.942-3.089)$ & $2.74 \pm 0.285$ & 0.017 \\
\hline \multicolumn{7}{|l|}{ GC localization } \\
\hline Multi site & 36 & $2.923(2.349-3.343)$ & $2.917 \pm 0.17$ & $2.83 \quad(1.942-3.175)$ & $2.787 \pm 0.252$ & 0.0051 \\
\hline Cardia & 10 & $2.929(2.802-3.175)$ & $2.947 \pm 0.095$ & $2.934(2.802-3.192)$ & $2.936 \pm 0.112$ & 0.91 \\
\hline Body & 1 & $2.997(-)$ & $2.997 \pm 0$ & $2.89(-)$ & $2.89 \pm 0$ & - \\
\hline Fundus & 1 & $3.104(-)$ & $3.104 \pm 0$ & $2.953(-)$ & $2.953 \pm 0$ & - \\
\hline Lesser curvature & 3 & $3.028(3.015-3.034)$ & $3.026 \pm 0.009$ & $2.969(2.914-3.009)$ & $2.964 \pm 0.047$ & - \\
\hline Pylorus & 2 & $2.934(2.911-2.956)$ & $2.934 \pm 0.032$ & $2.706(2.66-2.752)$ & $2.706 \pm 0.065$ & - \\
\hline \multicolumn{7}{|l|}{ Histological types } \\
\hline Diffuse & 15 & $2.916(2.729-3.109)$ & $2.943 \pm 0.087$ & $2.89 \quad(2.382-2.969)$ & $2.788 \pm 0.191$ & 0.025 \\
\hline Intestinal & 22 & $2.946(2.349-3.097)$ & $2.929 \pm 0.141$ & $2.891(2.541-3.139)$ & $2.872 \pm 0.151$ & 0.098 \\
\hline Indeterminated & 12 & $2.905(2.383-3.343)$ & $2.908 \pm 0.222$ & $2.85 \quad(1.942-3.175)$ & $2.746 \pm 0.341$ & 0.24 \\
\hline \multicolumn{7}{|l|}{ Tumor depth } \\
\hline $\mathrm{T} 1$ & 1 & $2.96(-)$ & $2.96 \pm 0$ & $2.88(-)$ & $2.88 \pm 0$ & - \\
\hline $\mathrm{T} 2$ & 8 & $2.913(2.383-3.034)$ & $2.871 \pm 0.204$ & $2.923(1.942-3.009)$ & $2.698 \pm 0.397$ & 0.87 \\
\hline $\mathrm{T} 3$ & 25 & $2.936(2.349-3.109)$ & $2.93 \pm 0.144$ & $2.859(2.417-3.175)$ & $2.862 \pm 0.163$ & 0.015 \\
\hline $\mathrm{T} 4$ & 16 & $2.924(2.729-3.343)$ & $2.957 \pm 0.134$ & $2.81 \quad(2.382-3.089)$ & $2.807 \pm 0.194$ & 0.048 \\
\hline \multicolumn{7}{|c|}{ Lymph nodes metastases } \\
\hline N0 & 14 & $2.972(2.383-3.1)$ & $2.917 \pm 0.177$ & $2.841(1.942-3.086)$ & $2.734 \pm 0.319$ & 0.051 \\
\hline N1 & 7 & $2.936(2.863-3.017)$ & $2.942 \pm 0.054$ & $2.817(2.752-3.175)$ & $2.89 \pm 0.146$ & 0.2 \\
\hline N2 & 14 & $2.923(2.349-3.012)$ & $2.888 \pm 0.163$ & $2.901(2.382-3.139)$ & $2.855 \pm 0.176$ & 0.32 \\
\hline N3 & 15 & $2.931(2.802-3.343)$ & $2.991 \pm 0.147$ & $2.859(2.417-3.192)$ & $2.846 \pm 0.205$ & 0.074 \\
\hline \multicolumn{7}{|l|}{ Distant metastases } \\
\hline M0 & 36 & $2.931(2.349-3.343)$ & $2.922 \pm 0.168$ & $2.853(1.942-3.175)$ & $2.799 \pm 0.249$ & 0.0061 \\
\hline M1 & 4 & $2.88 \quad(2.802-3.009)$ & $2.893 \pm 0.095$ & $2.796(2.583-2.989)$ & $2.791 \pm 0.203$ & - \\
\hline \multicolumn{7}{|l|}{ Histological grading } \\
\hline G1 & 1 & $3.034(-)$ & $3.034 \pm 0$ & $3.009(-)$ & $3.009 \pm 0$ & - \\
\hline $\mathrm{G} 2$ & 14 & $2.93 \quad(2.349-3.097)$ & $2.912 \pm 0.172$ & $2.952(2.581-3.139)$ & $2.912 \pm 0.24$ & 0.76 \\
\hline G3 & 33 & $2.916(2.383-3.343)$ & $2.928 \pm 0.144$ & $2.808(1.942-3.175)$ & $2.767 \pm 0.247$ & 0.0013 \\
\hline
\end{tabular}

The amount of AKR1C3 proteins was presented as the decimal logarithm of AKR1C3 to GAPDH band optical density ratio.

$\mathrm{P}<0.05$ was considered as statistically significant. * non-parametric, Mann-Whitney test

https://mc06.manuscriptcentral.com/bcb-pubs 
A

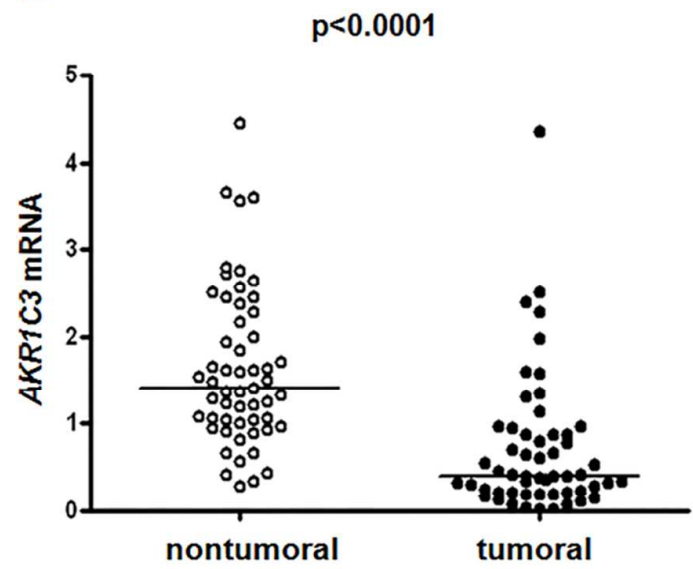

B

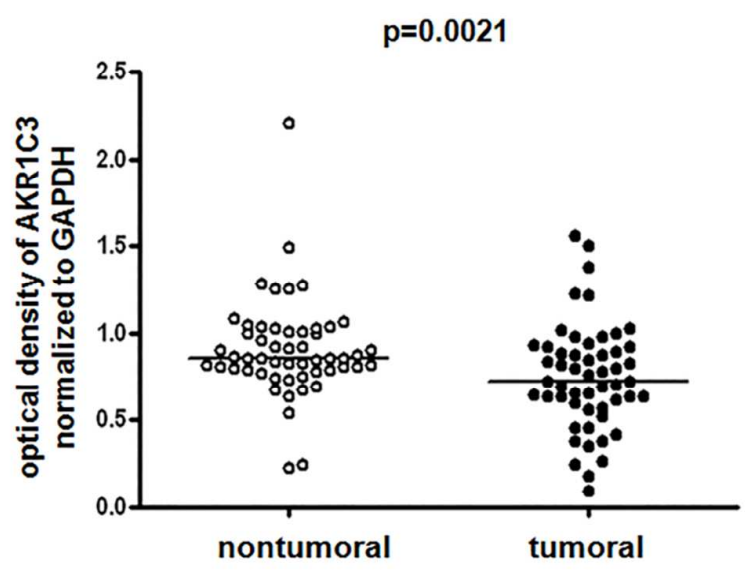

C
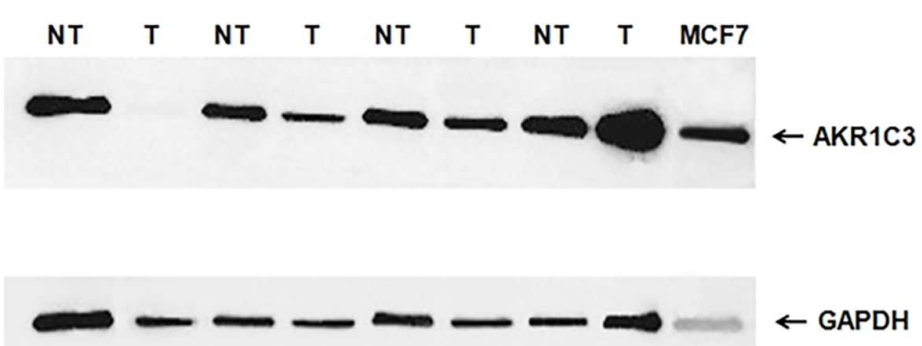

Fig. 1. AKR1C3 transcript (A) and protein (B) levels and a representative image of western blot analysis (C) of AKR1C3 presence in nontumoral (NT) and tumoral (T) tissues of patients with GC. The quantity of $A K R 1 C 3$ transcripts in each sample was standardized by the geometric mean of $B 2 M$ and GUSB cDNA levels and expressed as multiples of these cDNA in the calibrator. The amount of AKR1C3 protein was calculated as the AKR1C3 to GAPDH band optical density ratio. The "p" value was evaluated by Mann-Whitney Test. 

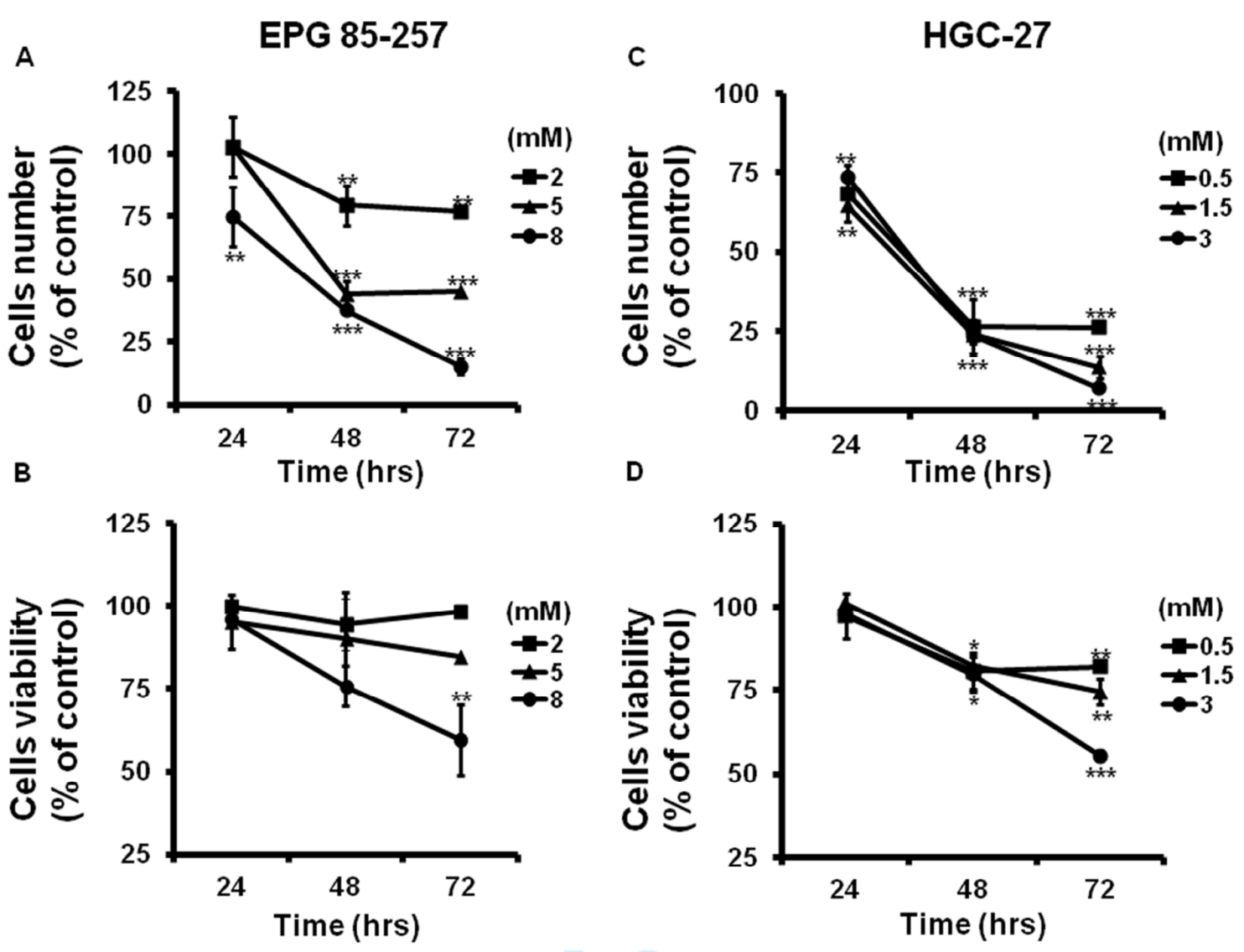

Fig. 2. NaBu inhibits proliferation (A,C) and viability (B,D) in EPG 85-257 and HGC-27 GC cells respectively. The cells were incubated for 24-78 hours and treated with the different concentrations of $\mathrm{NaBu}$. After incubation, the cells were harvested and the total number of both, viable (unstained) and unviable (stained) cells were calculated with using trypan blue dye. Proliferation rate of EPG 85-257 (A) and HGC-27 (C) cells was represented as percent of total (stained and unstained) cell numbers of respective control. EPG 85-257 (B) and HGC-27 (D) GC cells viability was calculated with using following equation: total viable cells (unstained)/total cells (stained and ustained) $\mathrm{x} 100$ and represented as a percent of respective control. Each sample was determined in triplicate and results are presented as the mean \pm SD from three experiments. ${ }^{*} \mathrm{p}<0.05 ;{ }^{*} \mathrm{p}<0.01 ;{ }^{* *} \mathrm{p}<0.001$ 
A

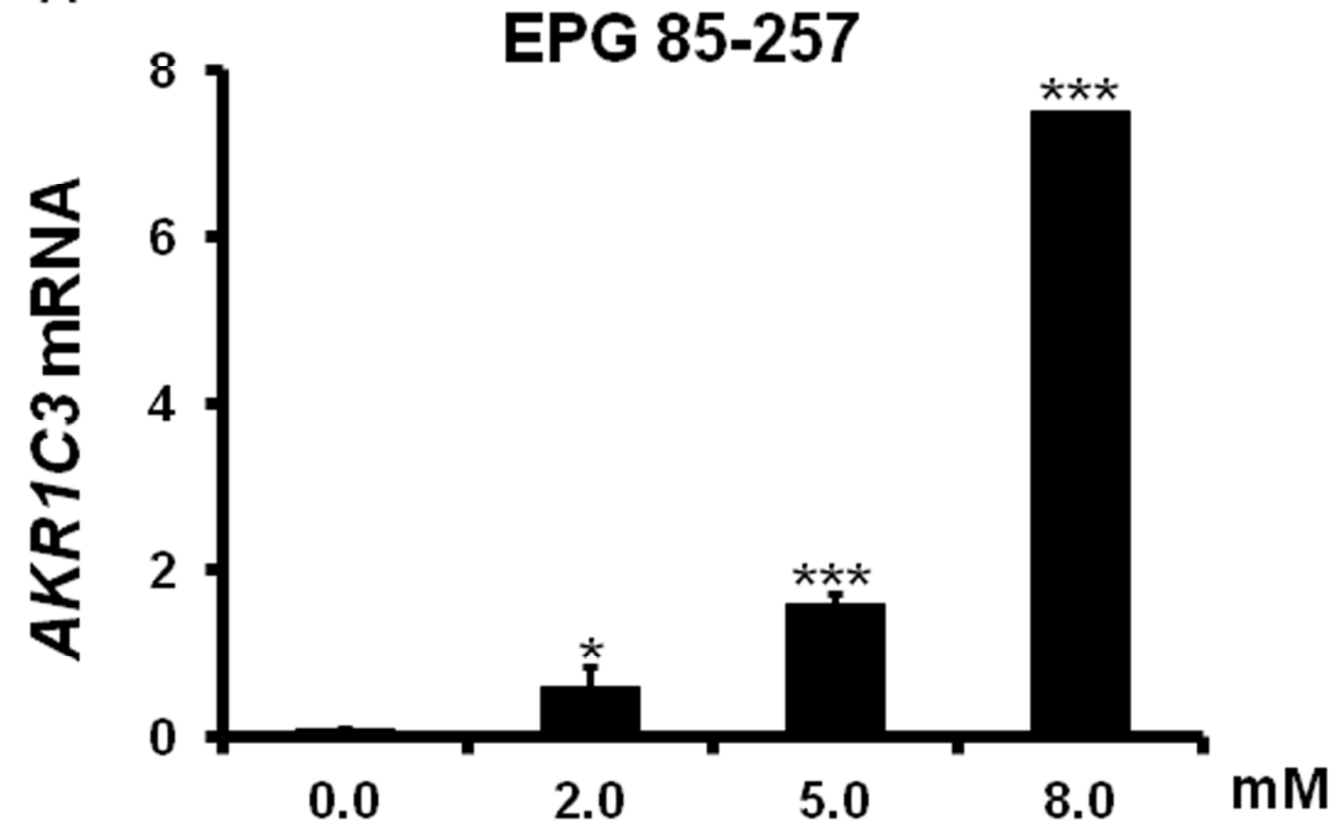

B

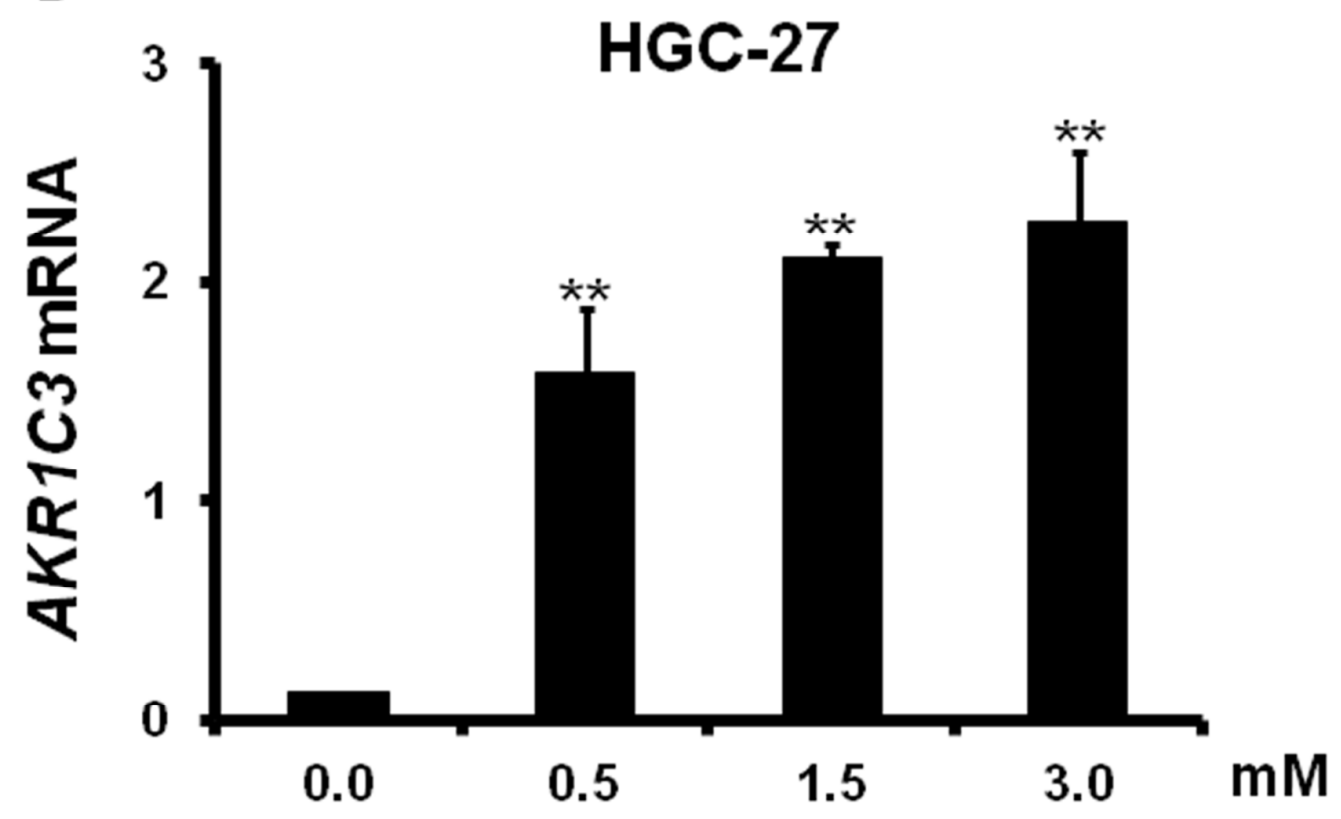

Fig. 3. NaBu increases AKR1C3 transcript levels in EPG 85-257 (A) and HGC-27 (B) GC cells. The cells were cultured for 72 hours in an appropriate phenol red-free medium either in the absence $(0.0)$ or in the presence of $\mathrm{NaBu}$ at the concentrations of 2.0, 5.0 and 8.0mM for EPG 85-257 and 0.5, 1.5 and 3.0mM for HGC-27 GC cells. After incubation, the cells were used for total RNA isolation and reverse transcription. The $A K R 1 C 3 \mathrm{cDNA}$ levels were determined by RQ-PCR relative quantification 
analysis. RQ-PCR results were standardized by the geometric mean of $B 2 M$ and GUSB cDNA levels. $A K R 1 C 3$ cDNA levels were expressed as a multiplicity of the respective controls. Each sample was determined in triplicate and results are presented as the mean $\pm \mathrm{SD}$ from three experiments. ${ }^{*} \mathrm{p}<0.05$; $* * \mathrm{p}<0.01 ; * * * \mathrm{p}<0.001$

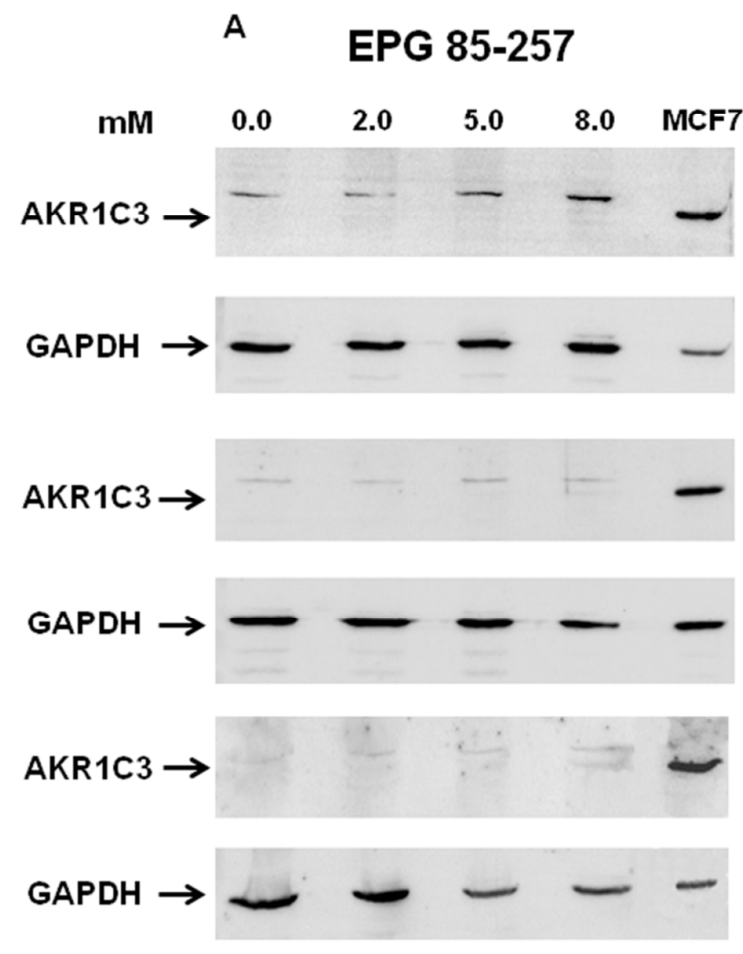

B

\section{HGC-27}

24
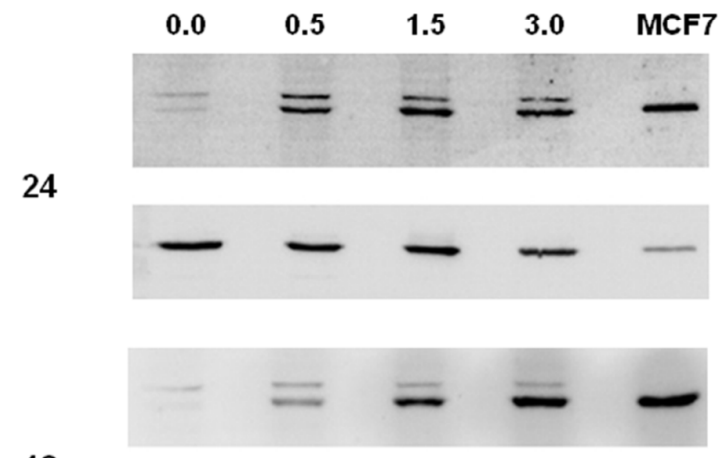

48

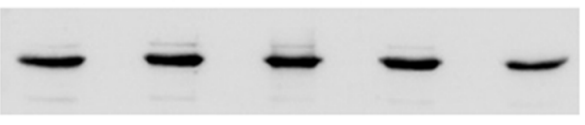

72

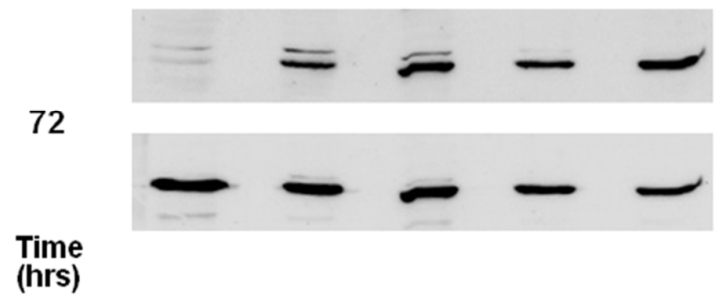

Fig. 4. NaBu increased AKR1C3 proteins level in EPG 85-257 (A) and HGC-27 (B) GC cells.

The cells were cultured for 24, 48 and 72 hours in an appropriate phenol red-free medium either in the absence or in the presence of $\mathrm{NaBu}$ at the concentrations of 2.0, 5.0 and 8.0mM for EPG 85-257 and 0.5, 1.5 and 3.0mM for HGC-27 GC cells. The cells protein were separated by $12 \%$ SDS-PAGE, and transferred to a membrane that was then immunoblotted with rabbit polyclonal anti-AKR1C3 Ab and incubated with goat anti-rabbit HRP-conjugated Ab. After stripping, the membrane was reblotted with rabbit polyclonal anti-GAPDH $\mathrm{Ab}$ and goat anti-rabbit HRP-conjugated $\mathrm{Ab}$. The band densitometry readings were normalized to GAPDH loading control. 
A

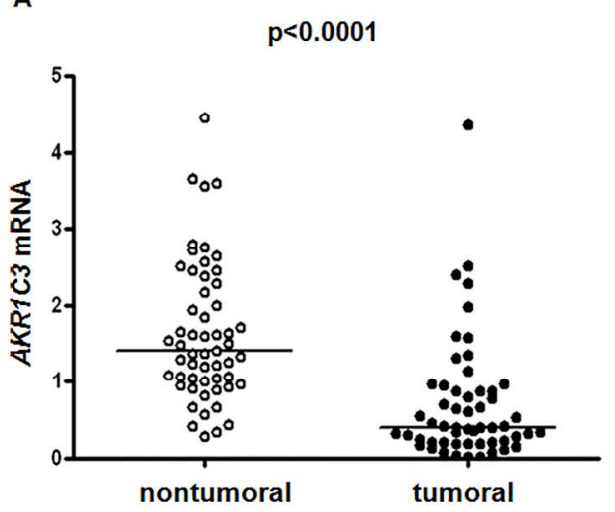

B

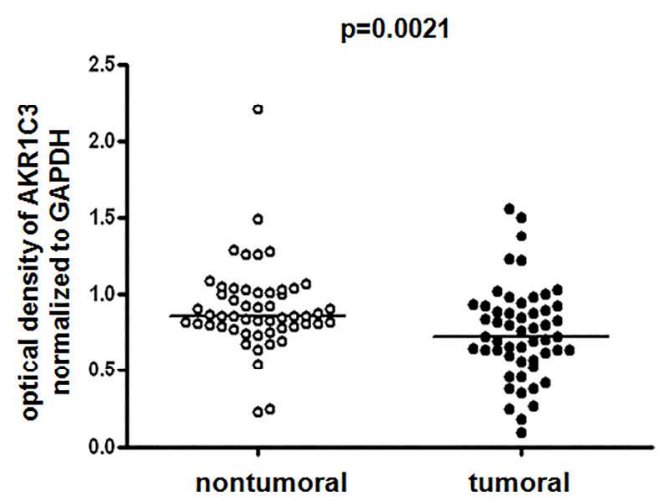

C
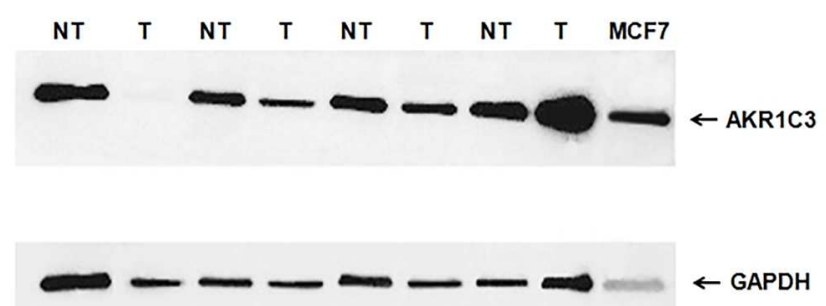

Fig. 1. AKR1C3 transcript (A) and protein (B) levels and a representative image of western blot analysis (C) of AKR1C3 presence in nontumoral (NT) and tumoral (T) tissues of patients with GC. The quantity of $A K R 1 C 3$ transcripts in each sample was standardized by the geometric mean of B2M and GUSB cDNA levels and expressed as multiples of these CDNA in the calibrator. The amount of AKR1C3 protein was calculated as the AKR1C3 to GAPDH band optical density ratio. The " $p$ " value was evaluated by Mann-Whitney Test. $263 \times 186 \mathrm{~mm}(300 \times 300 \mathrm{DPI})$ 

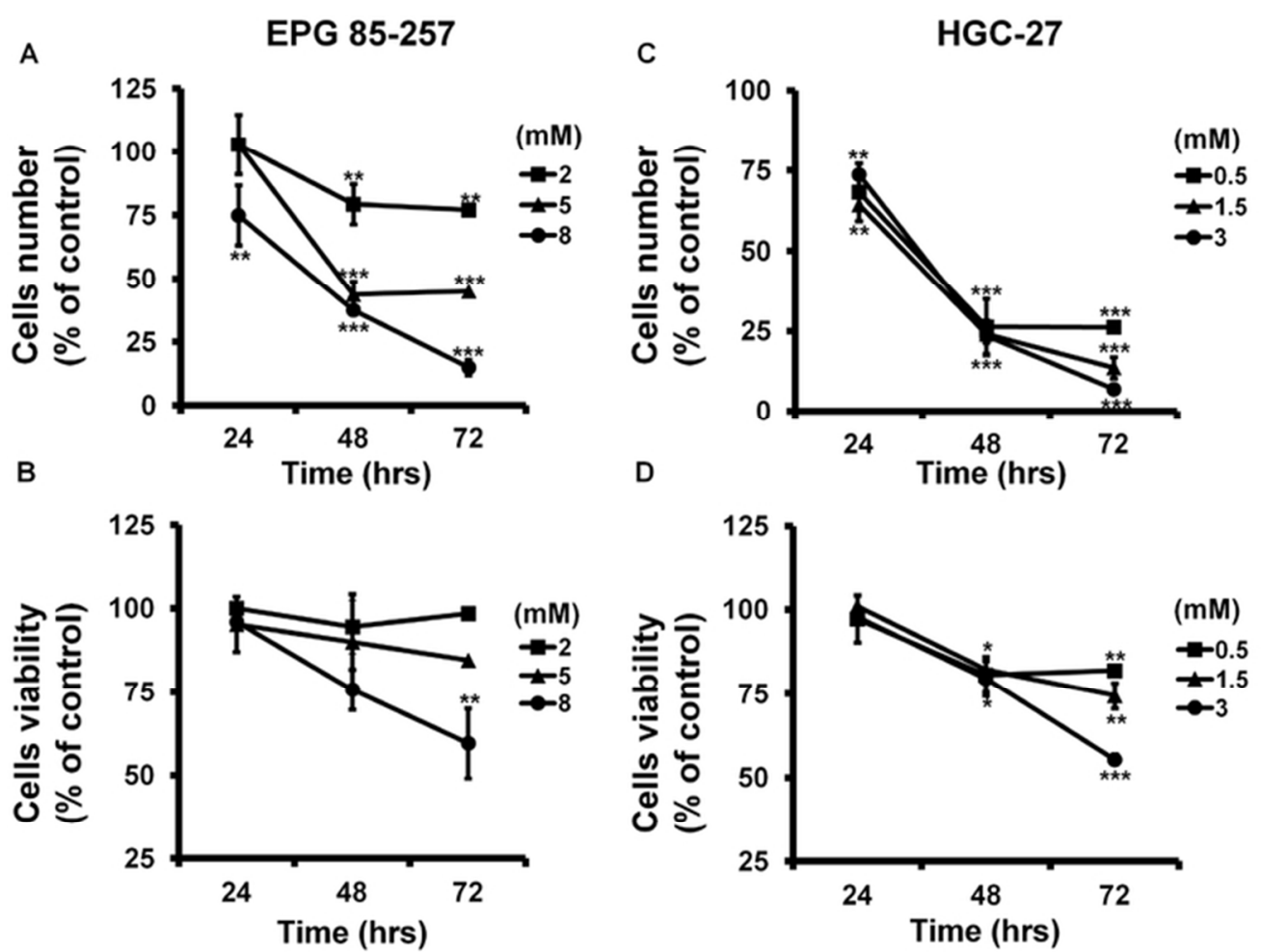

Fig. 2. NaBu inhibits proliferation (A,C) and viability (B,D) in EPG 85-257 and HGC-27 GC cells respectively. The cells were incubated for 24-78 hours and treated with the different concentrations of NaBu. After incubation, the cells were harvested and the total number of both, viable (unstained) and unviable (stained) cells were calculated with using trypan blue dye. Proliferation rate of EPG 85-257 (A) and HGC-27 (C) cells was represented as percent of total (stained and unstained) cell numbers of respective control. EPG 85-257

(B) and HGC-27 (D) GC cells viability was calculated with using following equation: total viable cells (unstained)/total cells (stained and ustained) $\times 100$ and represented as a percent of respective control. Each sample was determined in triplicate and results are presented as the mean \pm SD from three experiments. $* p<0.05 ; * * p<0.01 ; * * * p<0.001$. $64 \times 48 \mathrm{~mm}(300 \times 300$ DPI) 


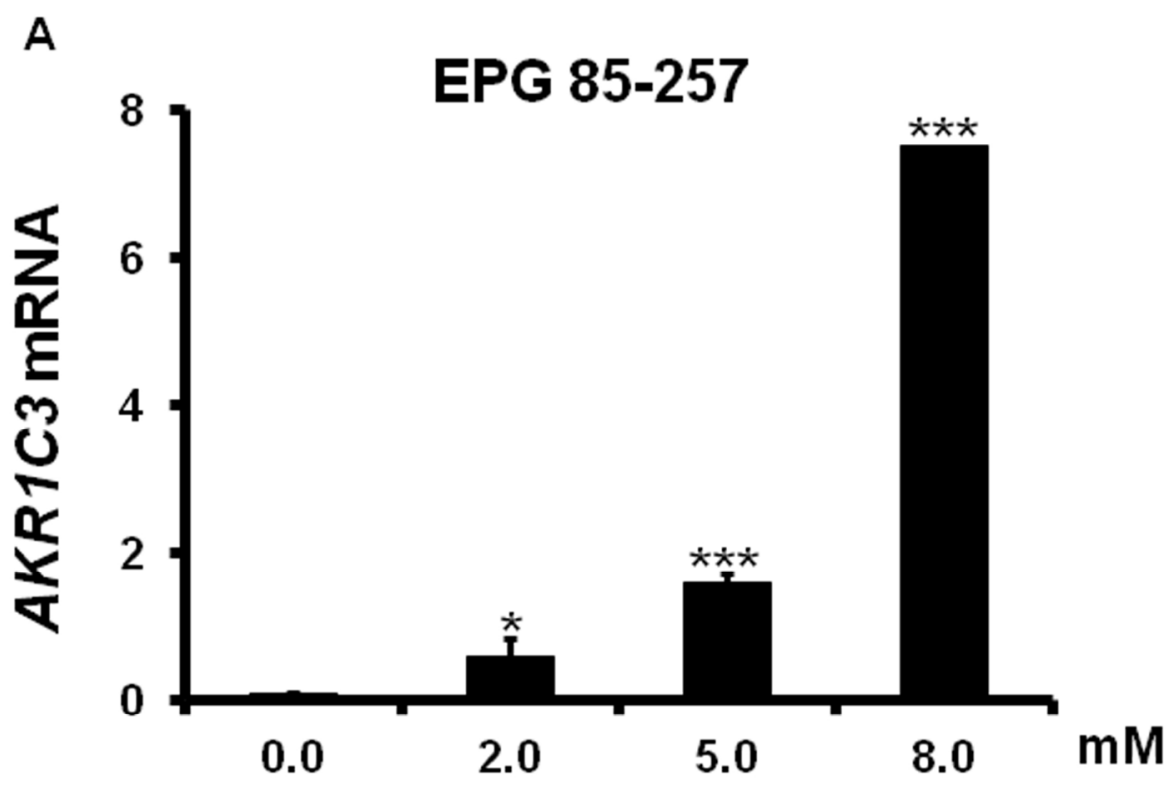

B

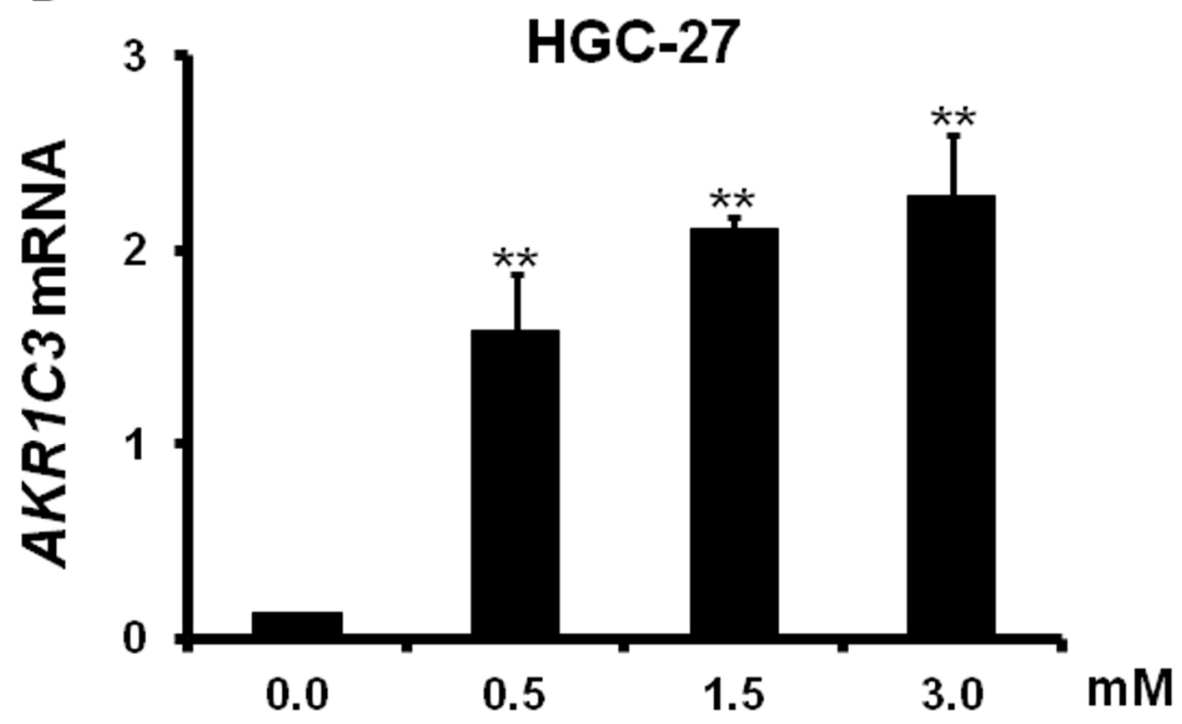

Fig. 3. NaBu increases $A K R 1 C 3$ transcript levels in EPG 85-257 (A) and HGC-27 (B) GC cells. The cells were cultured for 72 hours in an appropriate phenol red-free medium either in the absence $(0.0)$ or in the presence of $\mathrm{NaBu}$ at the concentrations of 2.0, 5.0 and $8.0 \mathrm{mM}$ for EPG 85-257 and 0.5, 1.5 and 3.0mM for HGC-27 GC cells. After incubation, the cells were used for total RNA isolation and reverse transcription. The $A K R 1 C 3$ CDNA levels were determined by RQ-PCR relative quantification analysis. RQ-PCR results were standardized by the geometric mean of B2M and GUSB CDNA levels. AKR1C3 CDNA levels were expressed as a multiplicity of the respective controls. Each sample was determined in triplicate and results are presented as the mean \pm SD from three experiments. $* p<0.05 ; * * p<0.01 ; * * * p<0.001$. $190 \times 247 \mathrm{~mm}(300 \times 300 \mathrm{DPI})$ 


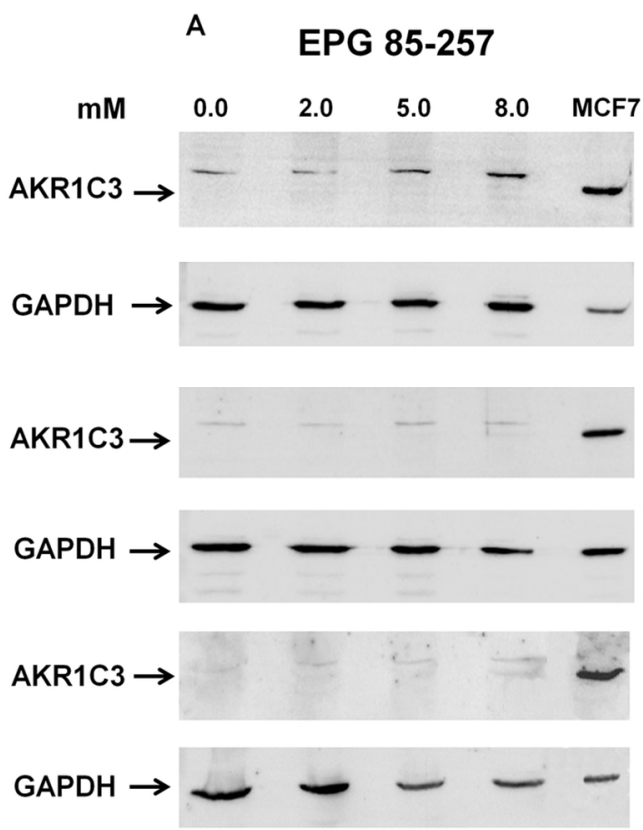

24

\section{B HGC-27}
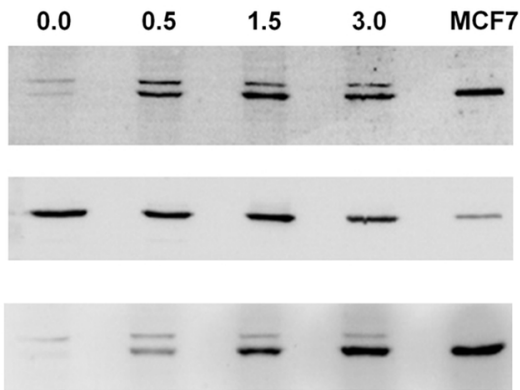

48
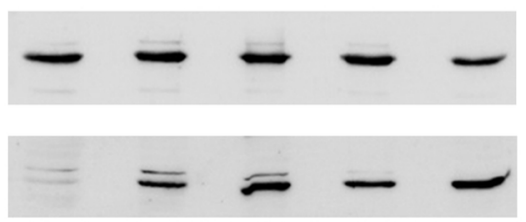

72

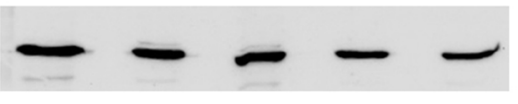

(hrs)

Fig. 4. NaBu increased AKR1C3 proteins level in EPG 85-257 (A) and HGC-27 (B) GC cells. The cells were cultured for 24, 48 and 72 hours in an appropriate phenol red-free medium either in the absence or in the presence of $\mathrm{NaBu}$ at the concentrations of 2.0, 5.0 and 8.0mM for EPG 85-257 and 0.5, 1.5 and 3.0mM for HGC-27 GC cells. The cells protein were separated by $12 \%$ SDS-PAGE, and transferred to a membrane that was then immunoblotted with rabbit polyclonal anti-AKR1C3 Ab and incubated with goat anti-rabbit HRPconjugated $\mathrm{Ab}$. After stripping, the membrane was reblotted with rabbit polyclonal anti-GAPDH Ab and goat anti-rabbit HRP-conjugated $\mathrm{Ab}$. The band densitometry readings were normalized to GAPDH loading control. $122 \times 81 \mathrm{~mm}(300 \times 300$ DPI $)$ 